\title{
CIMETIDINE AS A PROPHYLACTIC AGAINST ACID ASPIRATION AT TRACHEAL EXTUBATION
}

\author{
DENNIS W. CoOmbs AND DONALD W. HoOPER
}

\begin{abstract}
Gastric acidity was studied immediately after induction of balanced anaesthesia and again just before extubation of the trachea in 76 elective surgical patients. In 26 patients who were not given cimetidine before operation, the mean gastric $\left[\mathrm{H}^{+}\right]$at intubation was $2.6 \times 10^{-2} \pm 2.3 \times$ $10^{-2} \mathrm{mEq} / 1(\mathrm{pH} 2.02 \pm 0.22)$ and was more than $3.16 \times 10^{-3} \mathrm{mEq} / 1(\mathrm{pH}<2.5)$ in 53 per cent at extubation (mean $\left[\mathrm{H}^{+}\right] 3.0 \times 10^{-2} \pm 2.2 \times 10^{-2} \mathrm{mEq} / 1 ; \mathrm{pH} 1.83 \pm 0.22$ ). In contrast, of those premedicated with intravenous cimetidine 45 minutes before tracheal intubation, none had a gastric $\left[\mathrm{H}^{+}\right]$more than $3.16 \times 10^{-3} \mathrm{mEq} / 1(\mathrm{pH}<2.5)$ irrespective of the duration of the operation (15-180 minutes). However, of those patients receiving cimetidine 15 minutes before intubation, one-third failed to achieve a gastric $\left[\mathrm{H}^{+}\right]$less than $3.16 \times 10^{-3} \mathrm{mEq} / \mathrm{l}(\mathrm{pH}>$ 2.5) at the time of extubation. Properly timed premedication with intravenous cimetidine will reduce the risk of acid-related pulmonary damage if aspiration occurs at the time of intubation or extubation. Repeated administration should be considered when the interval between premedication and extubation exceeds four hours.
\end{abstract}

Key Words: Aspiration, acid; Prophylaxis, cimetidine.

PULMONARY ACID aspiration at induction of anaesthesia is a generally acknowledged hazard. The danger of aspiration following extubation of the trachea is less commonly appreciated. Recent reports of catastrophic aspiration pneumonitis in obstetrical patients re-emphasize pulmonary injury from aspiration with or following tracheal extubation. ${ }^{1}$ Histamine-2 receptor antagonism with cimetidine has been shown to reduce the risk of pulmonary damage induced by acid aspiration at the time of induction of anaesthesia and tracheal intubation. ${ }^{2-4}$ Richardson et al. have shown a significant reduction in gastric acid secretion in duodenal ulcer patients up to five hours following cimetidine administration. ${ }^{5}$ We reasoned therefore that histamine-2 receptor blockade established before induction of anaesthesia would produce an "envelope" or period of safety against damage to the lung attributable to acid in aspirated gastric contents.

Dennis W. Coombs, M.D., Assistant Professor, Department of Surgery (Anaesthesia - Critical Care) Donald Hooper, M.D., Assistant Professor of Clinical Surgery (Anaesthesia), Dartmouth-Hitchcock Medical Center, Hanover, New Hampshire, 03755 U.S.A.

This work was done in the Section of Anaesthesia, Department of Surgery at the Dartmouth-Hitchcock Medical Center, Hanover, New Hampshire.

Address reprint requests to: Dennis $W$. Coombs M.D., Department of Surgery (Anaesthesia - Critical Care), Dartmouth-Hitchcock Medical Center, Hanover, New Hampshire 03755 U.S.A.

Canad. Anaesth. Soc. J., vol. 28, no. 1, January 1981
A study was initiated to compare the reduction in gastric acidity at intubation and extubation related to the time after cimetidine premedication. For the purpose of this study the risk of pulmonary injury is reduced when gastric $\left[\mathrm{H}^{+}\right]$is less than $3.16 \times 10^{-3} \mathrm{mEq} / 1(\mathrm{pH}>2.5)$, as previously defined by Teabault $^{6}$ and Roberts and Shirley. ${ }^{7}$ Though gastric volume aspirated is an important variable in pulmonary damage from acid aspiration, gastric $\left[\mathrm{H}^{+}\right]$less than $3.16 \times 10^{-3}$ $\mathrm{mEq} / 1(\mathrm{pH}>2.5)$ will virtually eliminate the risk of acid-induced pulmonary aspiration injury, irrespective of volume. Because of the difficulty of accurate measurement of gastric volume no attempt was made to ascertain it during operation. Moreover there is controversy over the effect of cimetidine on gastric volume..$^{3,4,8}$

\section{Methods}

Seventy-six adult patients (age 18-65), ASA physical status I or II, were studied during general endotracheal anaesthesia for uncomplicated gynaecological or orthopedic operations. Written informed consent was obtained from each patient the evening before the operation. Approval was given by the institution's committee for the protection of human subjects. Patients were assigned to a placebo control group (no cimetidine) or to a 


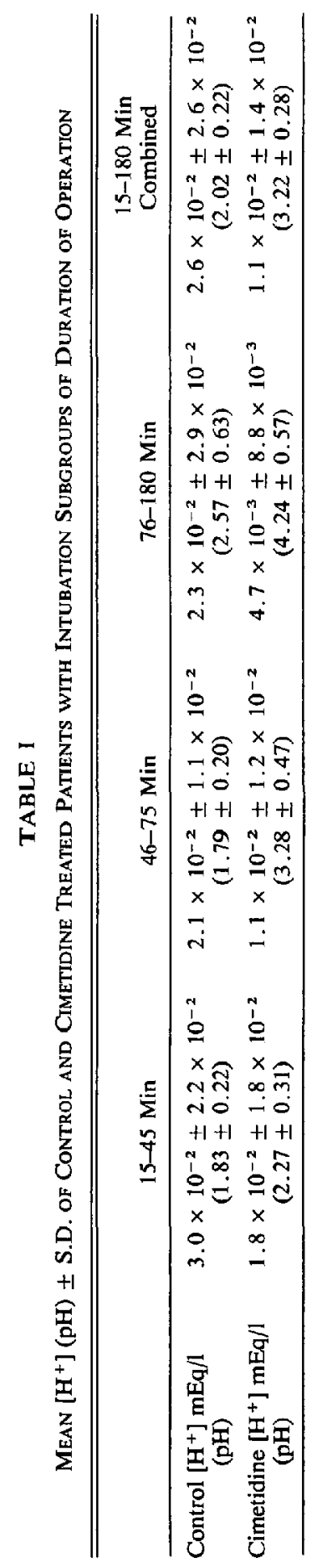


TABLE II

Mean $\left[\mathrm{H}^{+}\right] \mathrm{mEq} / \mathrm{l}(\mathrm{pH}) \pm$ S.D. of Control and Cimetidine Treated Patients at Extubation by Subgroups of DuRATION OF OPERATION

\begin{tabular}{lccc}
\hline \hline & $15-45 \mathrm{Min}$ & $46-75 \mathrm{Min}$ & $76-180 \mathrm{Min}$ \\
\hline Control & $3.3 \times 10^{-2} \pm 2.2 \times 10^{-2}$ & $2.9 \times 10^{-2} \pm 2.0 \times 10^{-2}$ & $1.5 \times 10^{-2} \pm 1.7 \times 10^{-2}$ \\
& $(1.74 \pm .22)$ & $(1.61 \pm .26)$ & $(2.26 \pm .3)$ \\
& $(32.7 \pm 1.96 \mathrm{~min})$ & $(61.0 \pm 2.92 \mathrm{~min})$ & $(129.4 \pm 14.44 \mathrm{~min})$ \\
$15 \mathrm{Min}$ & $5.4 \times 10^{-3} \pm 7.9 \times 10^{-3}$ & $3.9 \times 10^{-3} \pm 4.6 \times 10^{-3} \dagger$ & $1.9 \times 10^{-3} \pm 2.5 \times 10^{-3} \ddagger$ \\
& $(3.44 \pm .61)$ & $(4.14 \pm 1.84) \dagger$ & $(4.44 \pm 1.78) \ddagger$ \\
& $(31.1 \pm 2.95 \mathrm{~min})$ & $(56.7 \pm 4.91 \mathrm{~min})$ & $(113.3 \pm 14.8)$ \\
$30 \mathrm{Min}$ & $8.4 \times 10^{-4} \pm 1.3 \times 10^{-4 *}$ & $1.8 \times 10^{-4} \pm 3.1 \times 10^{-4} \dagger$ & $2.8 \times 10^{-4} \pm 6.8 \times 10^{-4} \ddagger$ \\
& $(4.62 \pm .77)^{*}$ & $(5.06 \pm .6) \dagger$ & $(6.82 \pm .89) \ddagger$ \\
& $(28.3 \pm 3.33 \mathrm{~min})$ & $(59.5 \pm 2.56 \mathrm{~min})$ & $(101.7 \pm 9.46 \mathrm{~min})$ \\
$45 \mathrm{Min}$ & $3.0 \times 10^{-6} \pm 4.0 \times 10^{-6 *}$ & $2.4 \times 10^{-4} \pm 3.5 \times 10^{-4} \dagger$ & $2.1 \times 10^{-5} \pm 3.4 \times 10^{-5} \ddagger$ \\
& $(6.47 \pm .75)^{*}$ & $(5.07 \pm .80) \dagger$ & $(5.4 \pm .6) \ddagger$ \\
& $(32.5 \pm 5.2 \mathrm{~min})$ & $(57.4 \pm 1.94 \mathrm{~min})$ & $(116.7 \pm 24.6 \mathrm{~min})$ \\
\hline
\end{tabular}

$* \mathrm{p} 0.001$.

$+p=0.008$

$\ddagger \mathrm{p}=0.009$.

operation. Treated patients received cimetidine $300 \mathrm{mg}$ intravenously depending on the predictability of the time interval from premedication to induction, so that inclusion into a treated group would not delay the surgical schedule unduly. The control patients were selected similarly by exclusion from the longer treatment intervals and received instead a placebo of one $\mathrm{ml}$ of sterile saline given intravenously 15 minutes before induction of anaesthesia. Twenty-six patients make up the saline placebo group and 50 patients the cimetidine group. The treated group was further subdivided into three subgroups on the basis of the interval from premedication to induction of anaesthesia. These subgroups were composed as follows: 16 patients with a 15 minute time interval from pretreatment to induction, 20 patients with a 30 minute interval, and 14 patients with a 45 minute interval.

All patients received morphine sulphate 0.1 $\mathrm{mg} \cdot \mathrm{kg}^{-1}$ and pentobarbitone $1 \mathrm{mg} \cdot \mathrm{kg}^{-1}$ intramuscularly one hour before anaesthesia. Belladonna drugs were not given. Saline placebo one $\mathrm{ml}$ or intravenous cimetidine $300 \mathrm{mg}$ at a rate of $150 \mathrm{ml}$ per minute were given and the time to induction was recorded. Anaesthesia was induced in all patients after intravenous gallamine triethiodide $15 \mathrm{mg}$ and three minutes of preoxygenation. Rapid intravenous induction with thiopentone $4 \mathrm{mg} \cdot \mathrm{kg}^{-1}$ and succinylcholine chloride $1.5 \mathrm{mg} \cdot \mathrm{kg}^{-1}$ then preceded immediate tracheal intubation. Balanced anaesthesia was maintained with 70 per cent nitrous oxide and 30 per cent oxygen, morphine analgesia, and either succinylcholine chloride or pancuronium

TABLE III

Relationship Between Premedication to Induction InTERVAL, Surgical Duration at Extubation, AND Frequency of Gastric Extubation $\left[\mathrm{H}^{+}\right]<3.16$ $\times 10^{-3}(\mathrm{pH}>2.5)$

\begin{tabular}{llccc}
\hline \hline & \multicolumn{4}{c}{ Surgical Duration } \\
\cline { 2 - 5 } & $15-45$ & $46-75$ & $76-180$ & $(15-180)$ \\
\hline Control & $1 / 13$ & $0 / 5$ & $2 / 8$ & $3 / 26$ \\
15 Min & $7 / 10$ & $2 / 3$ & $2 / 3$ & $11 / 16^{*}$ \\
30 Min & $5 / 6$ & $8 / 8$ & $6 / 6$ & $19 / 20 \dagger$ \\
45 Min & $4 / 4$ & $7 / 7$ & $3 / 3$ & $14 / 14 \ddagger$ \\
\hline
\end{tabular}

${ }^{*} \mathrm{p}<.001$.

tp $<.001$.

$\ddagger \mathrm{p}<.001$.

bromide for muscle relaxation. Immediately after tracheal intubation, an \#18 Levine tube was placed in the stomach and a $5-10 \mathrm{ml}$ aliquot of gastric content was removed for determination of acidity. Similarly, a final specimen was removed just before tracheal extubation for acid determination and the time was recorded. Acid determinations were done with an Ionalyzer Orion Research Digital pH Meter No. 801 and a Fisher Scientific Microprobe Combination Electrode No. 13-639-92.

Statistical analysis of results involved one-way analysis of variance for comparison of mean $\left[\mathrm{H}^{+}\right]$ (pH) in control and cimetidine-treated patients and chi-square for a linear trend in proportions for frequency of the gastric acid risk factor (gastric $\left[\mathrm{H}^{+}\right]>3.16 \times 10^{-3} ; \mathrm{pH}<2.5$ ) between sub- 
groups of control and treated patients. ${ }^{9}$ This statistical approach was chosen in acknowledgement of the recent controversy over analysis of $\mathrm{pH}$ data and because mean gastric $\mathrm{pH}$ demonstrated homogeneity of variance in the population analyzed. ${ }^{3,10-12}$

\section{Results}

The mean $\left[\mathrm{H}^{+}\right](\mathrm{pH})$ at intubation of control and subgroups of cimetidine treated patients is shown in Table I. The gastric $\left[\mathrm{H}^{+}\right]$was more than $3.16 \times 10^{-3} \mathrm{mEq} / 1(\mathrm{pH}<2.5)$ in 80.8 per cent of control patients at intubation. In contrast, the mean $\left[\mathrm{H}^{+}\right]$progressively decreased $(\mathrm{pH}$ increased) as compared to control in cimetidinetreated patients as premedication to induction interval increased (highly significant; $\mathbf{P}<$ 0.0001 ).

The mean $\left[\mathrm{H}^{+}\right]$at extubation of all control patients increased from $2.6 \times 10^{-2} \pm 2.3 \times 10^{-2}$ $\mathrm{mEq} / 1$ at intubation to $3.0 \times 10^{-2} \pm 2.2 \times 10^{-2}$ $\mathrm{mEq} / \mathrm{l}$ at extubation ( $\mathrm{pH}$ fell from 2.02 to 1.83 ). Of 26 control patients, the gastric $\left[\mathrm{H}^{+}\right]$at extubation was higher than at intubation in 14 (53.8 per cent); 23 patients ( 88.5 per cent) had a gastric $\left[\mathrm{H}^{+}\right]$greater than $3.16 \times 10^{-3} \mathrm{mEq} / 1(\mathrm{pH}<2.5)$ at extubation.

Table II shows the mean $\left[\mathrm{H}^{+}\right](\mathrm{pH})$ at extubation of control and cimetidine treated subgroups subdivided into three groups by the interval between intubation and extubation. The mean $\left[\mathrm{H}^{+}\right]$ at extubation of each pretreatment interval was significantly decreased ( $\mathrm{pH}$ increased) over control for the three subgroups. Analysis of variance of the means of duration of operation within the subgroups (Table II) revealed no significant differences.

Table III shows the relationship between the premedication to induction interval and the timing of extubation as it influences the number or percentage of patients at risk at extubation (gastric $\left[\mathrm{H}^{+}\right]>3.16 \times 10^{-3} \mathrm{mEq} / 1 ; \mathrm{pH}<2.5$ ). No patient premedicated 45 minutes before the operation was at risk for a surgical procedure of 15 to 180 minutes duration. Similarly, a high degree of protection $\left(\left[\mathrm{H}^{+}\right]<3.16 \times 10^{-3} \mathrm{mEq} / \mathrm{l} ; \mathrm{pH}>2.5\right)$ was afforded by premedication 30 minutes before operation. However, about one third of patients premedicated 15 minutes before operation were still at relative risk for acid pulmonary damage irrespective of the length of the surgical procedure (15-180 minutes), had aspiration occurred.

\section{Discussion}

Acid aspiration is a risk to the surgical patient throughout the peri-operative period, including tracheal extubation. Though numerous studies have documented low gastric $\mathrm{pH}$ (high $\left[\mathrm{H}^{+}\right]$) following intubation ${ }^{3,4,7,8}$ even in elective surgical patients, little attention has been given to the risk of acid aspiration with extubation. During intubation, unconsciousness and paralysis are rapidly produced. In contrast, extubation often takes place when emergence of consciousness, residual paralysis, and vagal tone are more difficult to assess. Emergence from anaesthesia is further complicated by the presence of cholinesterase inhibitors (increased vagal tone), narcotics (increased biliary pressure and chemoreceptor trigger zone stimulation), and post-operative pain with secondary delayed gastric emptying, ileus. These factors may predispose to post-operative emesis when upper airway protective reflexes are insufficient to prevent pulmonary aspiration.

This study suggests that gastric $\left[\mathrm{H}^{+}\right]$is higher than $3.16 \times 10^{-3} \mathrm{mEq} / \mathrm{l}(\mathrm{pH}<2.5)$ in the majority of elective surgical patients following tracheal intubation. We have previously shown that intravenous cimetidine premedication results in a time dependent increase in post-induction gastric $\mathrm{pH}$ (decrease in $\left.\left[\mathrm{H}^{+}\right]\right)^{3}$. Continued high gastric $\left[\mathrm{H}^{+}\right]$(low $\mathrm{pH}$ ) after up to three hours of elective surgery was the rule in the control group of patients. The mean $\left[\mathrm{H}^{+}\right]$of the control group actually rose $(\mathrm{pH}$ fell) during operation under balanced anaesthesia. These data indicate continued autonomic activity and intra-operative stress under this kind of anaesthesia. Therefore the risk of acid aspiration is as likely at extubation as at induction of anaesthesia. This risk may be less at extubation if a sympatholytic inhalation anaesthetic has been administered ${ }^{13}$ instead of balanced anaesthesia.

Cimetidine premedication resulted in a significant decrease in gastric $\left[\mathrm{H}^{+}\right]$with intubation when administered 45 minutes before operation. Further, in this group gastric $\left[\mathrm{H}^{+}\right]$was significantly decreased ( $\mathrm{pH}$ increased) before extubation with surgical procedures from 15 to 180 minutes duration. This reduces the risk of lung injury by acid aspiration at the time of extubation of the trachea.

Unfortunately, a 45 minute premedication interval was more protective than 15 minutes in reducing the risk of pulmonary damage if aspiration had occurred with extubation, regardless of 
the length of the surgical procedure. Before being aware of the data we had assumed that gastric acidity 45 to 60 minutes following cimetidine would show a similar decrease in gastric $\left[\mathrm{H}^{+}\right]$ (increase in $\mathrm{pH}$ ) at extubation whether or not anaesthesia induction and intubation occurred less than 45 minutes following premedication. The most plausible explanation for this disparity is the inhibition of gastric emptying associated with anaesthesia and caused in part by vagal stimulation of parietal cell receptors by anaesthesia drugs. Reduction in total gastric acid volume is a function of acid produced, acid removed or buffered by metabolic activity, and gastric emptying. Cimetidine itself does not affect gastric emptying. ${ }^{14}$ However, the $\mathrm{H}-2$ receptor is probably separate from the acetycholine and gastrin receptors in parietal cells, though $\mathrm{H}-2$ stimulation increases the affinity of the parietal cell for gastrin and acetylcholine. ${ }^{15} \mathrm{H}-2$ receptor blockade initiated immediately before or after induction of anaesthesia may be inadequate to block parietal cell acid production completely in the presence of an intense induction stimulus, while pre-existing gastric acid will accumulate by virtue of anaesthetic-induced delay in gastric emptying.

This study provides guidelines for the best use of the prophylactic potential of cimetidine against the hazard of acid aspiration injury to the lung at extubation. Cimetidine $300 \mathrm{mg}$ should be given intravenously at least 30 minutes and preferably 45 minutes before induction of anaesthesia. In addition, during prolonged operations, repeated administration of cimetidine should be contemplated every three to four hours after induction and intubation until the trachea has been extubated, and even beyond until airway reflexes and mental faculties have returned. These findings may not apply to the $\mathrm{H}-2$ receptor blockade when it is initiated the evening before operation, as advocated by Weber and Hirsham. ${ }^{16}$ Our clinical experience has shown this to be an acceptable protocol, except where patients have not been premedicated with cimetidine and it is desired to initiate an $\mathrm{H}-2$ receptor blockade before operation (i.e., the patient is found to have significant oesophageal reflux, or protection against passive regurgitation is desired. ${ }^{17}$ ) If properly applied, $\mathrm{H}-2$ receptor blockade may significantly reduce peri-operative risk of acid aspiration pulmonary injury by creating an "envelope of safety" at least three hours in duration, encompassing both induction and extubation.

\section{REFERENCES}

1. Whittington, R., Robinson, J. \& Thompson, J. Fatal Aspiration (Mendolson's syndrome) Despite Antacids and Cricoid Pressure. Lancet II: 228-30, 1979.

2. Husemeyer, R.P., DAVENPort, H.T. \& Rajasekarant. Cimetidine as a Single Oral Dose for Prophylaxis Against Mendelson's Syndrome. Anaesthesia 33: 775-78, 1978.

3. Coombs, D. Hooper, D. \& Colton, T. Preanesthetic Cimetidine Alteration of Gastric Fluid Volume and pH. Anesth. Analg. (Cleve) 58: 183-89, 1979.

4. Coombs, D., Hooper, D. \& Colton, T. AcidAspiration Prophylaxis by use of Preoperative Oral Administration of Cimetidine. Anesthesiology 51 : 352-56, 1979.

5. Richardson, C., Walsh, J. \& Hicks, M.I. The Effect of Cimetidine, a New Histamine $\mathrm{H}-2 \mathrm{Re}-$ ceptor Antagonist on Meal Stimulated Acid Secretion, Serum Gastrin, and Gastric Emptying in $\mathrm{Pa}$ tients with Duodenal Ulcer. Gastroenterology $7 l$ : $19-23,1976$.

6. Teabeaut, J.R. Aspiration of Gastric Contents: Experimental Study. Am. J. Pathol. 28: 51-62, 1952.

7. Roberts, R. \& Shirley, M. Reducing the Risk of Acid Aspiration During Cesarean Section. Anesth. Analg. (Cleve) 53; 859-63, 1974.

8. MaliniaK, K. \& VAKIL, A. Pre-anesthetic Cimetidine and Gastric pH. Anesth. Analg. 58: 309-13, 1979.

9. ARMITAge, P. Statistical Methods in Medical Research. New York, John Wiley and Sons, 1971. pp. 269-275, 363-65.

10. Feinstein, A. On Central Tendency and the Meaning of Mean for $\mathrm{pH}$ Values. Anesth. Analg. (Cleve) $58: 1-3,1979$.

11. Krause, P. Statistical Analysis of $\mathrm{pH}$ Data. Anesth. Analg. (Cleve) 57: 143-44, 1978.

12. Giesecke, A.H., Beveh, C.W. \& Kallus, F.T. More on Interpretation of pH Data. Anesth. Analg. (Cleve) 57: 379-81, 1978.

13. Christenson, V. \& Skovsted, P. Effects of General Anesthetics on the $\mathrm{pH}$ of Gastric Contents in Man During Surgery. Acta Anaesthesiol. Scand. 19: $49-54,1975$

14. Longstreth, A.F., Go, V.L.W. \& MalageLADA, J.-R. Postprandial Gastric, Pancreatic and Biliary Response to Histamine H2-Receptor Antagonists in Active Duodenal Ulcer. Gastroenterology 72:9-13, 1977.

15. Finkelstein, W. \& Isselbacher, K. Cimetidine (in Drug Therapy, Koch-Weser J-Editor) N. Eng. J. Med. 299: 992-96, 1978.

16. Weber, L. \& Hirshman, C. Cimetidine for Prophylaxis of Aspiration Pneumonitis: Comparison of Intramuscular and Oral Dosage Schedules. Anesthesiology Supplement (Abst.) 51: S180, 1979.

17. TuRndorf, H., Rodis, I. \& Clark, T. "Silent" Regurgitation During General Anesthesia. Anesth. Analg. 53: 700-703, 1974. 


\section{RÉSUMÉ}

On a mesuré le $\mathrm{pH}\left[\mathrm{H}^{+}\right]$de liquide gastrique immédiatement aprés l'intubation et juste avant l'extubation chez des opérés sous anesthésie génerale (thiopental, succinylcholine, intubation, protoxyde d'azote, oxygéne, morphine curarisants). Des valeurs supérieures à $\left[\mathrm{H}^{+}\right] 3.16$ $\times 10^{-3} \mathrm{mEq} / \mathrm{l}(\mathrm{pH}<2.5)$ (moyenne: $\left[\mathrm{H}^{+}\right] 2.6 \times 10^{-2} \mathrm{mEq} / \mathrm{l}:(\mathrm{pH} 2.02)$, ont été retrouvées chez 80.8 pour cent des patients immédiatement après l'intubation et chez 88.5 pour cent des sujets (moyenne: $\left[\mathrm{H}^{+}\right] 3.0 \times 10^{-2} \mathrm{mEq} / \mathrm{l}: \mathrm{pH} 1.83$ ) juste avant l'extubation lorsque les malades n'avaient pas reçu de cimethidine pré-opératoire. On sait qu'un liquide gastrique de $\left[\mathrm{H}^{+}\right]$ inférieur a $3.16 \times 10^{-3} \mathrm{mEq} / \mathrm{l}(\mathrm{pH}>2.5)$ élimine virtuellement les dangers de pneumonite liés à l'acidité du liquide, en cas d'aspiration.

Aucun des malades ayant reçu une dose intraveineuse de $300 \mathrm{mg}$ de cimethidine 45 minutes avant le début de l'intubation n'a présenté de liquide gastrique de $\left[\mathrm{H}^{+}\right]$supérieur à $3.16 \times$ $10^{-3} \mathrm{mEq} / \mathrm{l}(\mathrm{pH}<2.5)$ et ce, quelle que soit la durée de interventions (15 à 180 minutes). Lorsque la cimethidine était administrée moins de 15 minutes avant l'induction, un $\left[\mathrm{H}^{+}\right]$ supérieur à $3.16 \times 10^{-3} \mathrm{mEq} / \mathrm{l}(\mathrm{pH}<2.5)$ était observé chez le tiers des malades au moment de l'extubation.

Une dose de cimethidine administrée au bon moment, avant l'induction de l'anesthésie, réduit donc le risque de complications respiratoires liées à l'acidité du liquide gastrique, en cas d'aspiration. On devrait envisager la possibilité de répéter la dose de cet agent lorsque la durée de l'intervention semble devoir dépasser quatre heures. 